Gut, 1978, 19, 408-413

\title{
Immunohistochemical localisation of urogastrone to human duodenal and submandibular glands
}

\author{
Ph.U. HEITZ1, MARLIS KASPER, SUSAN VAN NOORDEN, JULIA M. POLAK, \\ H. GREGORY, AND A. G. E. PEARSE \\ From the Department of Pathology, University of Basle, Switzerland, Department of Histochemistry, \\ Royal Postgraduate Medical School, London, and ICI Ltd, Pharmaceuticals Division, Alderley Park, \\ Macclesfield, Cheshire
}

SUMMARY Urogastrone has been localised by immunostaining to granules of the cells of human duodenal (Brunner's) glands and their ducts and of acinar cells in the human submandibular gland. The immunoreactive peptide is present in large quantities in duodenal glands and their secretory ducts. Urogastrone or human epidermal growth factor promotes cellular proliferation in vivo as well as in vitro and inhibits gastric acid secretion and may, therefore, be one of the duodenal factors inhibiting gastric activity. Thus it may have an important regulatory and protective function for the intestinal mucosa and may possibly become a useful therapeutic agent.

Forty years ago it was shown that extracts of the urine of pregnant women have a beneficial effect on peptic ulcers (Sandweiss et al., 1938). Later it was reported that extracts from pregnancy urine as well as from normal human urine cause an inhibition of gastric secretion (Culmer et al., 1939; Gray et al., 1939). The active principle was named urogastrone because of its possible relationship to enterogastrone, a postulated duodenal hormone inhibiting gastric acid secretion (Gray et al., 1940).

Recently, urogastrone has been isolated from normal male urine (Gregory and Willshire, 1975). Subsequently, two active components were isolated and designated as $\beta$ - and $\gamma$-urogastrone respectively. Amino acid sequencing revealed that both substances consist of single polypeptide chains with three internal disulphide bonds containing $53(\beta)$ and 52 $(\gamma)$ amino acid residues (MW approximately 6000 daltons; Gregory, 1975; Gregory and Preston, 1977).

Attempts to find the source of human urogastrone were largely unsuccessful (Fitzgerald et al., 1968). However, the production of antibodies allowed the localisation of urogastrone in cells of human submandibular glands by an immunofluorescence technique (Elder et al., 1976). Moreover, urogastrone

${ }^{1}$ Address for correspondence: Dr Ph.U. Heitz, University of Basle, Schönbeinstrasse 40, CH-4056 Basle, Switzerland.

Received for publication 9 December 1977 was tentatively localised to duodenal glands ${ }^{2}$. The present investigation was carried out in order to establish the precise localisation of urogastrone in human tissue, using fixation techniques which had previously been successful in the localisation of the chemically and biologically similar mouse epidermal growth factor (EGF) (Van Noorden et al., 1977).

\section{Methods}

The material consisted of fresh operative samples of tissue surrounding tumours of human submandibular and parotid glands and kidney. Further operative and bioptic samples were obtained from pancreas, corpus, and antrum of the stomach, duodenum, jejunum, ileum, and colon. All specimens were considered to be normal at histological examination.

Some of the tissue was quenched in melting Arcton (Freon) ${ }^{22}$ at $-156^{\circ} \mathrm{C}$, freeze-dried overnight in a thermoelectric freeze-drier at $-40^{\circ} \mathrm{C}$, vapour fixed at $+60^{\circ} \mathrm{C}$ for three hours with formaldehyde, diethylpyrocarbonate (DEPC) or benzoquinone vapour (Pearse and Polak, 1975), and embedded in paraffin. Additional specimens were immersed in methanol-free formaldehyde (MFF) (Polak et al., 1971) and were subsequently dehydrated and embedded in paraffin.

'Slides shown by Dr J. Elder at the first International Symposium on Gastrointestinal Hormones held at Asilomar, California, in October 1976. 
PREPARATION OF ANTIBODIES

Antisera to urogastrone were raised in male Dutch rabbits. The animals received $1 \mathrm{mg} 10 \%$ pure urogastrone (Gregory and Willshire, 1975) in Freund's complete adjuvant by subcutaneous injection to four sites on each thigh. At monthly intervals the animals received additional subcutaneous or intracutaneous injections of $0.2 \mathrm{mg}$ pure urogastrone in Freund's incomplete adjuvant. They were bled from the ear vein approximately two weeks after boosting. The antiserum was diluted with an equal volume of saturated ammonium sulphate solution at $+4{ }^{\circ} \mathrm{C}$ and centrifuged. The precipitate was resuspended in $50 \%$ saturated ammonium sulphate and again collected by centrifugation. It was then desalted by dissolving it in $0.01 \mathrm{M}$ phosphate buffer $\mathrm{pH} 8.1$ and carrying out gel chromatography on Sephadex G-50 in the same buffer. The high molecular weight fraction was divided into small samples which were lyophilysed. Before use these were dissolved in water to the original volume of serum. This material bound $50 \%$ of the urogastrone labelled with $125 \mathrm{I}$ at a final dilution of $1 / 75000$. The preparation of iodinated urogastrone and the technique of the radioimmunoassay are described in detail elsewhere (Gregory et al., 1977).

\section{STAINING}

Paraffin sections $(5 \mu \mathrm{m})$ were stained with haematoxylin and eosin, PAS, and thiosulphation-aldehyde fuchsin (Bussolati and Bassa, 1974). Additional sections were incubated for urogastrone by the unlabelled antibody enzyme method (Sternberger, 1974) using rabbit antihuman urogastrone (dilution $1 / 200)$ as the first layer, sheep antirabbit IgG (1/30), and soluble peroxidase-antiperoxidase complexes
$(1 / 30)$ as second and third layers respectively. The histochemical reaction for peroxidase was carried out using 3,3'-diaminobenzidine tetrahydrochloride $(0.5 \mathrm{mg} / \mathrm{ml})$ and hydrogen peroxide $(0.01 \%)$ in $0.05 \mathrm{M}$ Tris-HCl buffer (pH 7.6). After fixation with osmium tetroxide $(1 \%)$ in phosphate buffered saline $(\mathrm{pH} 7 \cdot 2)$ the sections were dehydrated and mounted. Control reactions were carried out as follows: (1) anti-urogastrone serum absorbed with pure $\beta$-urogastrone $(100 \mu \mathrm{g} / \mathrm{ml}$ diluted serum) as first layer; (2) anti-urogastrone serum absorbed with freeze dried and acetone-treated human duodenal mucosa and submucosa $(660 \mu \mathrm{g} / \mathrm{ml}$ diluted serum); (3) anti-urogastrone serum absorbed with pentagastrin $(880 \mu \mathrm{g} / \mathrm{ml}$ diluted serum) or with freezedried and acetone-treated human liver powder $(500 \mu \mathrm{g} / \mathrm{ml}$ diluted serum); (4) non-immune rabbit serum as first layer; (5) inappropriate antisera as first layer (anti-secretin, anti-cholecystokinin, anti-somatostatin, anti-gastrin, and anti-glucagon); (6) omission of 3,3'-diaminobenzidine-tetrahydrochloride or hydrogen peroxide from the incubating medium for the peroxidase reaction.

\section{Results}

The best fixation for urogastrone was found to be formaldehyde vapour. Benzoquinone, DEPC, and liquid formaldehyde were less satisfactory.

Positive granular immunostaining was restricted to the submandibular gland acini and the duodenal (Brunner's) gland acini and ducts. Nearly all the cells of the duodenal glands displayed positive urogastrone immunoreactivity localised to the supranuclear part of cytoplasm (Fig. 1a, 3b). The intensity of immunostaining increased progressively from the cells of duodenal glands to those
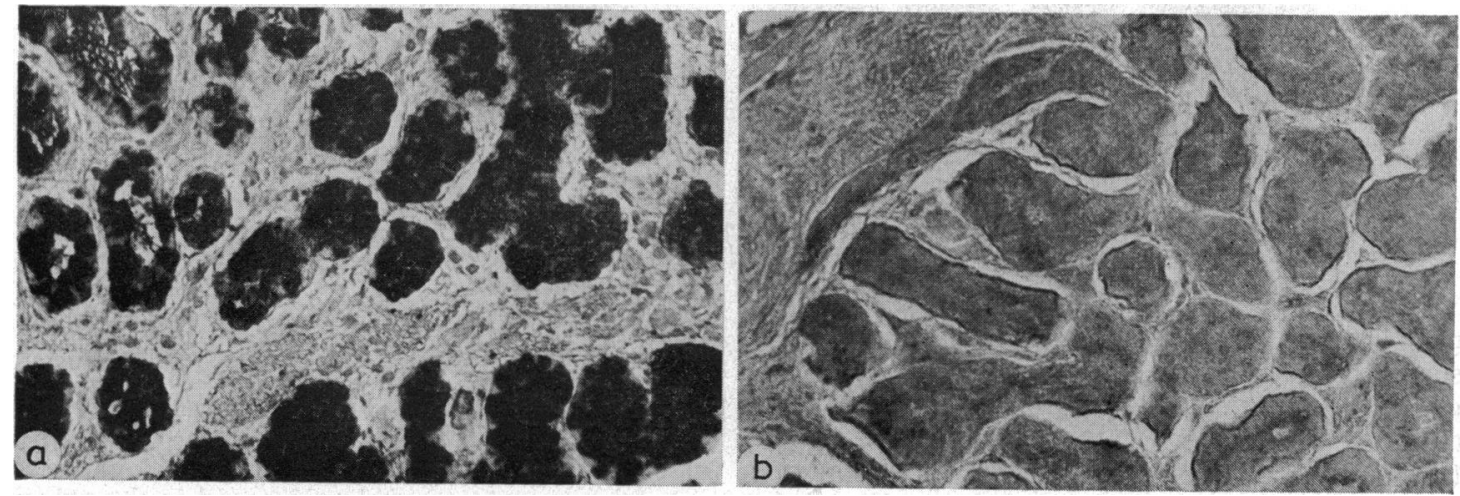

Fig. 1 (a) Intense urogastrone immunoreactivity in cells of duodenal glands. $\times 213$. (b) Negative control: incubation with anti-urogastrone serum previously absorbed with $\beta$-urogastrone $(100 \mu \mathrm{g} / \mathrm{ml}$ diluted serum $) . \times 213$. (original magnification). This and the other figures are of freeze-dried tissues fixed in formaldehyde vapour, except that of Fig. $3 a$, which was fixed in methanol-free formaldehyde. 5 um paraffin sections. Unlabelled antibody enzyme method. 


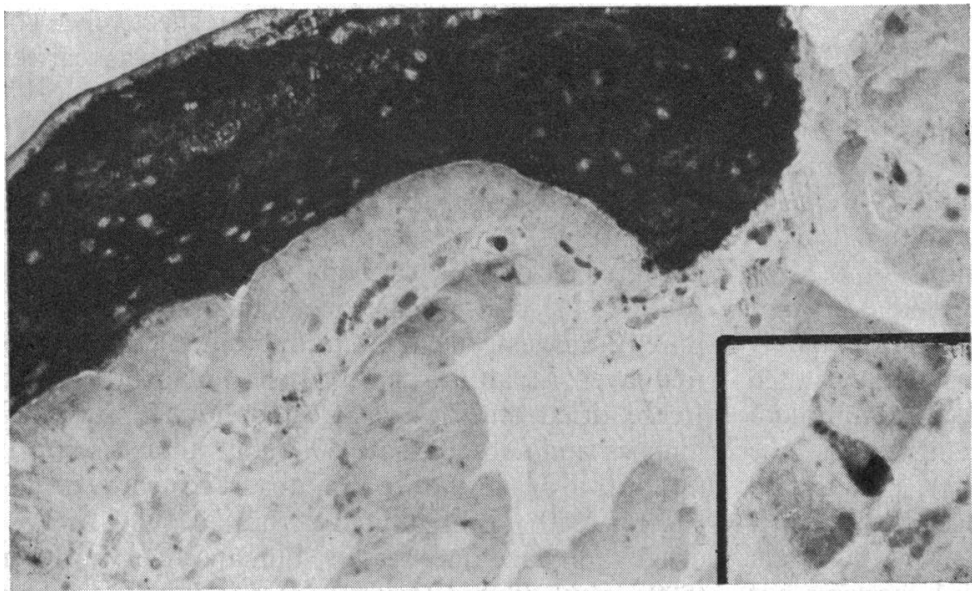

Fig. 2 Strong reaction for urogastrone in the surface film of duodenum. $\times 213$. Inset: cell in the epithelium of duodenal villus with immunostaining. $\times 213$.
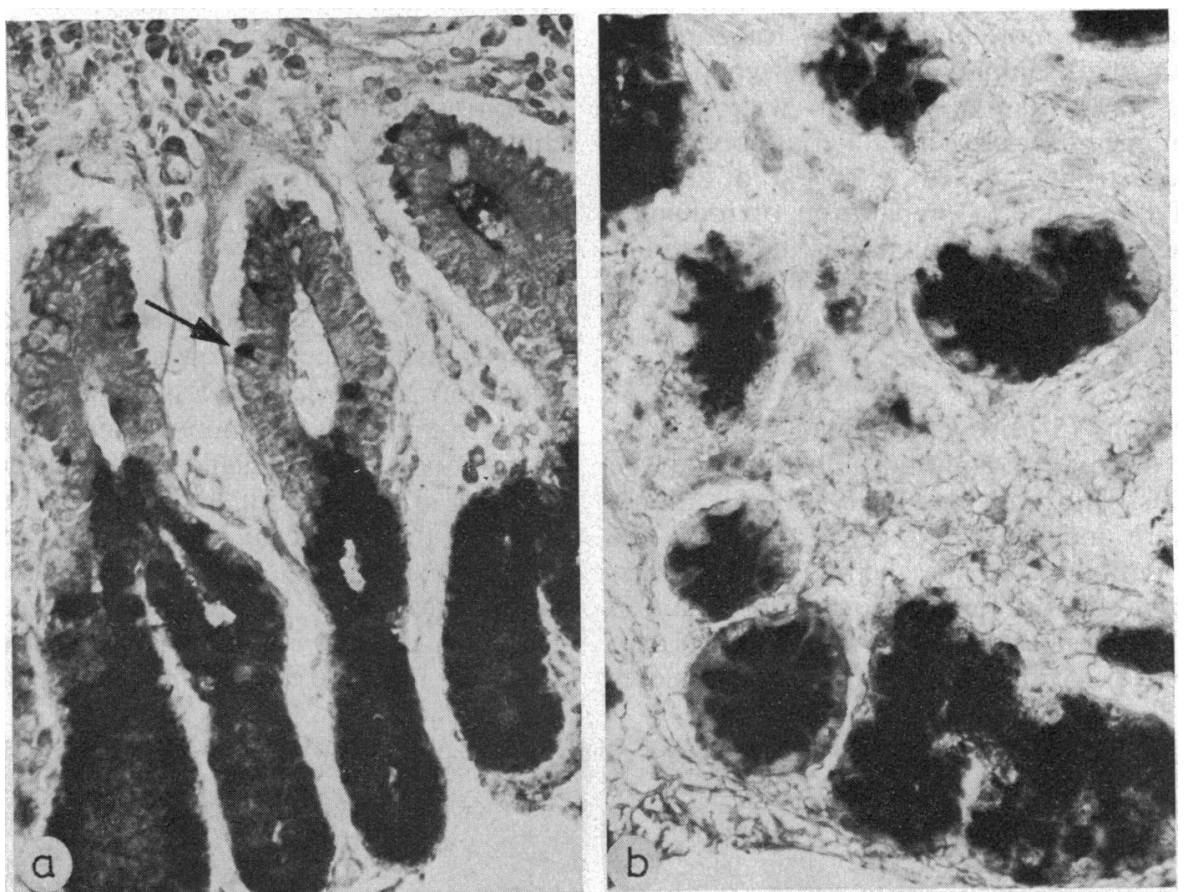

Fig. 3. (a) Immunostaining is confined to duct cells of duodenal glands. Only very few cells in the duodenal crypt epithelium are stained (arrow). $\times 213$. (b) The immunostain is localised to the supranuclear cytoplasm of cells of duodenal glands. $\times 333$.

of their ducts. There was a sharp delimitation of the staining at the junction of the ducts of the duodenal glands with the epithelium of the duodenal crypts (Fig. 3a). The content of the ducts as well as part of the duodenal surface film also showed a very intense reaction (Fig. 2, 3a). Only a very few cells of the duodenal crypt epithelium displayed a positive immunostain (Fig. 2). The granules of the duodenal gland cells stained strongly with PAS but only weakly with aldehyde fuchsin. In the submandibular glands the immunostain was confined to granules of some acinar cells (Fig. 4a, c, d). The duct cells did not show any reaction. Staining with aldehyde fuchsin was weak.

Immunostaining was also observed in the pyloric glands but was considered to be non-specific, as it persisted after incubation with anti-urogastrone serum preabsorbed with urogastrone. 

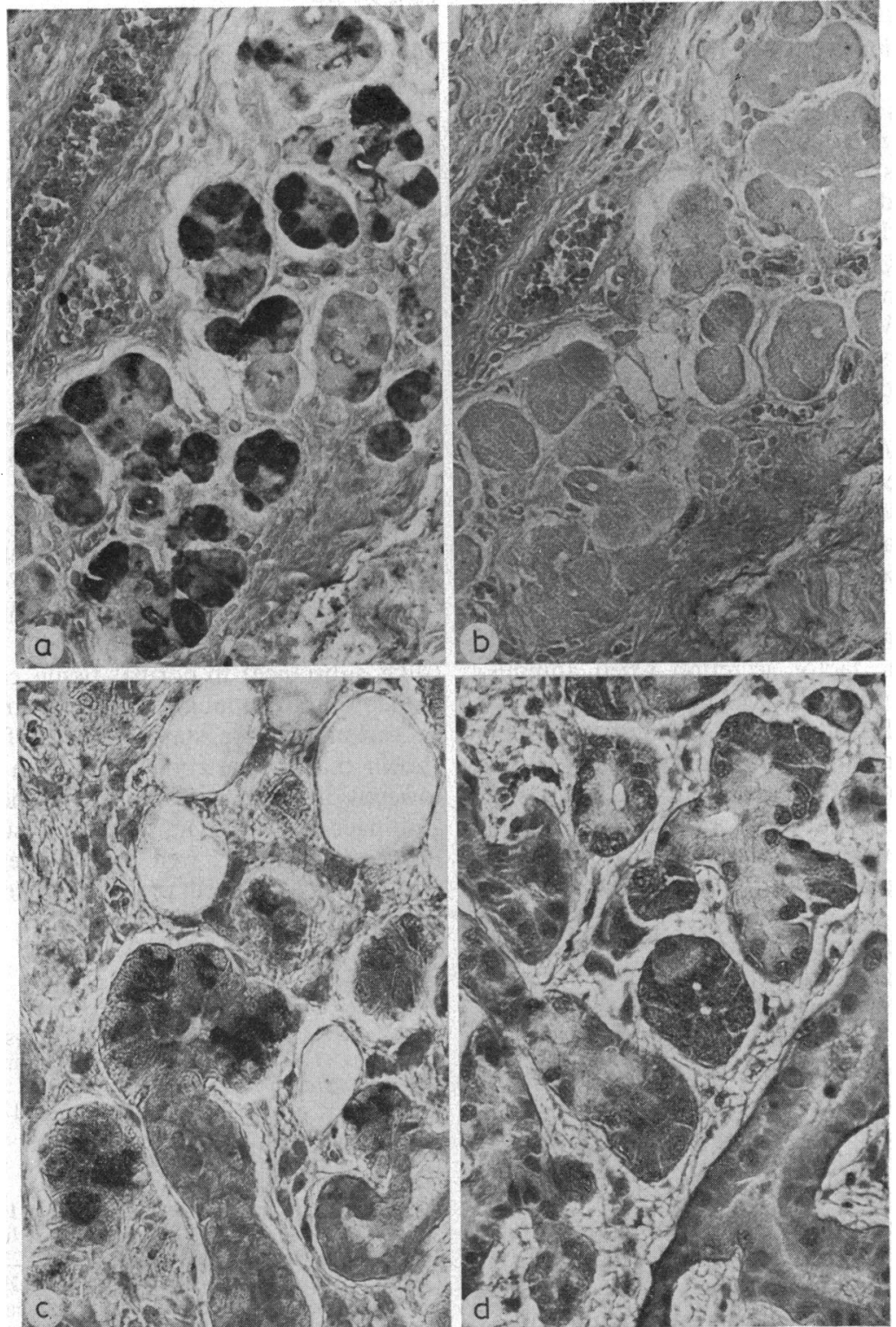

Fig. 4 Human submandibular gland. (a) Presence of urogastrone in acinar cells. $\times 213$. (b) Entirely negative reaction in section adjacent to that of Fig. 4 a after incubation with anti-urogastrone serum previously absorbed with $\beta$-urogastrone $(100 \mu \mathrm{g} / \mathrm{ml}$ diluted serum $) . \times 213$. (c) Immunostaining is confined to acinar cells. Duct cells are devoid of reaction product. $\times$ 333. $(d)$ Secretory granules are confined to acinar cells. $H$ and $E, \times 333$.

No immunostaining was seen in the other tissue samples which were tested.

The control reactions $1,2,4$, and 6 (see above) were invariably negative in both salivary and duodenal glands (Fig. 1b, 4b). Absorption with at least $100 \mu \mathrm{g} / \mathrm{ml}$ of $\beta$-urogastrone was required to quench the immunostain in the duct cells of the duodenal glands. Absorption with liver powder or pentagastrin had no effect on the immunostain and antisera other than anti-urogastrone stained the appropriate cells in the duodenal epithelium but very few cells in the glands.

\section{Discussion}

$\beta$-Urogastrone immunoreactivity has now been 
demonstrated in the cells of the duodenal (Brunner's) glands and in acinar cells of human submandibular glands.

Urogastrone is chemically unrelated to any of the peptides which are known to affect gastrointestinal function and this immunoreactive substance differs from such peptides in its cellular localisation and in its apparently exocrine mode of secretion, although some gastrointestinal endocrine peptides have been shown to be secreted partially into the lumen (Uvnäs-Wallensten, 1978). We must, for the moment, assume that this substance is the progenitor of urogastrone which is excreted in the urine, although this will be established only by further analysis. As the peptide was not found in the kidney, it must reach the blood stream by additional endocrine secretion or by reabsorption across the intestinal mucosa. Measurements of urogastrone levels will be needed to demonstrate its presence in the blood.

Urogastrone has been shown to inhibit gastric acid and intrinsic factor secretion when administered by infusion $(0.125-0.5 \mu \mathrm{g} / \mathrm{kg} / \mathrm{h})$ to normal human subjects (Elder et al., 1975b) and to patients with the Zollinger-Ellison syndrome (Elder et al., 1975a). The peptide also acts on isolated gastric mucosal preparations and has a beneficial effect on experimentally induced ulcers (Gregory, 1977). In addition, urogastrone stimulates DNA synthesis and the uptake of amino acids by cultured skin fibroblasts (Hollenberg and Gregory, 1976) and is stable to proteolytic enzymes such as trypsin, chymotrypsin, and pepsin (Gregory and Preston, 1977). It is thus conceivable that urogastrone is a protective factor with a dual action: inhibition of gastric acid secretion ('endocrine effect') on the one hand and stimulation of cell proliferation or regeneration of the intestinal mucosa ('exocrine effect') on the other.

Nothing is known about the regulation of urogastrone secretion but, as secretion by the duodenal glands depends on the content of the duodenal lumen and on neural and hormonal stimuli and as the response to food persists after extrinsic denervation (Davenport, 1977), it is probable that gastrointestinal hormones are involved. A variety of peptide hormone-secreting cells $\left(G, D\right.$, and $\left.D_{1}\right)$ have been found in the duodenal glands (Capella et al., 1976), so there is also the possibility of local peptide regulation.

Human urogastrone has biological actions identical with those of mouse EGF. The two substances have 37 out of their 53 amino acid residues in common (Cohen and Savage, 1974; Cohen and Taylor, 1974; Gregory and Preston, 1977) and share a receptor site in cultured human fibroblasts
(Hollenberg and Gregory, 1976). Gregory (1975) has suggested that urogastrone may be identical with a human epidermal growth factor such as that recently isolated from urine (Cohen and Carpenter, 1975; Starkey et al., 1975; Carpenter and Cohen, 1976). If this is so, the main site of production seems to be different in the two species, mouse EGF being found in the convoluted tubule cells of the submandibular gland ducts (Turkington et al., 1971; Van Noorden et al., 1977) and urogastrone mainly in the duodenal glands but also in the submandibular gland acini, rather than in the ducts.

Now that urogastrone-like immunoreactivity has been localised to the duodenal glands and in view of its potent inhibitory effect on gastric acid secretion, urogastrone seems to be a good candidate for the as yet unfilled niche of enterogastrone or bulbogastrone (Grossman et al., 1974).

The improved immunocytochemical techniques which have led to the localisation of urogastrone (-like substance) in normal tissue can now be extended to the examination of urogastrone production in various disease states. It may for example be shown that urogastrone production is significantly lowered in such diseases as peptic ulcer or the Zollinger-Ellison syndrome. In such conditions urogastrone may well have great therapeutic potential and indeed preliminary trials have been encouraging (Elder et al., 1975a).

\section{References}

Bussolati, G., and Bassa, T. (1974). Thiosulfation aldehyde fuchsin (TAF) procedure for the staining of pancreatic B cells. Stain Technology, 49, 313-315.

Capella, C., Solcia, E., Frigerio, B., and Buffa, R. (1976). Endocrine cells of the human intestine. An ultrastructural study. In Endocrine Gut and Pancreas, pp. 43-59. Edited by T. Fujita. Elsevier: Amsterdam.

Carpenter, G., and Cohen, S. (1976). Human epidermal growth factor and the proliferation of human fibroblasts. Journal of Cellular Physiology, 88, 227-238.

Cohen, S., and Carpenter, G. (1975). Human epidermal growth factor: isolation and chemical and biological properties. Proceedings of the National Academy of Sciences of the United States of America, 72, 1317-1321.

Cohen, S., and Savage, C. R., Jr (1974). Part 2. Recent studies on the chemistry and biology of epidermal growth factor. Recent Progress in Hormone Research, 30, 551-574.

Cohen, S., and Taylor, J. M. (1974). Part 1. Epidermal growth factor: Chemical and biological characterization. Recent Progress in Hormone Research, 30, 533-550.

Culmer, C. U., Atkinson, A. J., and Ivy, A. C. (1939). Depression of gastric secretion by the anterior pituitarylike fraction of pregnancy urine. Endocrinology, 24, 631-637.

Davenport, H. W. (1977). Physiology of the Digestive Tract, pp. 161-165. Year Book Medical Publishers, Chicago.

Elder, J. B., Ganguli, P. C., Gillespie, I. E., Delamore, W. I., and Gregory, H. (1975a). Effect of urogastrone in the Zollinger-Ellison syndrome Lancet, 2, 424-427. 
Elder, J. B., Ganguli, P. C., Gillespie, I. E., Gerring, E. L., and Gregory, H. (1975b). Effect of urogastrone on gastric secretion and plasma gastrin levels in normal subjects. Gut, 16, 887-893.

Elder, J. B , Williams, G., and Gregory, H. (1976). Cellular localization of urogastrone by an immunofluorescent technique. British Journal of Surgery, 63, 657. (Abstract.)

Fitzgerald, J. D., Barrett, A. M., and Gregory, H. (1968). An attempt to define the origin of human urogastrone. In The Physiology of Gastric Secretion (NATO Advanced Study Institute) pp. 408-411. Edited by L. S. Semb and J. Myren; Universitets Forlaget: Oslo.

Gray, J. S., Wieczorowski, E., and Ivy, A. C. (1939). Inhibition of gastric secretion by extracts of normal male urine. Science, 89, 489-490.

Gray, J. S., Wieczorowski, E., and Ivy, A. C. (1940). Inhibition of gastric secretion in man with urogastrone. American Journal of Digestive Diseases, 7, 513-515.

Gregory, H. (1975). Isolation and structure of urogastrone and its relationship to epidermal growth factor. Nature, 257, 325-327.

Gregory, H. (1977). Urogastrone and its relation to epidermal growth factor (Abstract). Gastroenterology, 72, No. 4, part 2, A5/815.

Gregory, H., Holmes, J. E., and Willshire, I. R. (1977). Urogastrone levels in the urine of normal adult humans. Journal of Clinical Endocrinology and Metabolism, 45, 668-672.

Gregory, H., and Preston, B. M. (1977). The primary structure of human urogastrone. International Journal of Peptide and Protein Research, 9, 107-118.

Gregory, H., and Willshire, I. R. (1975). The isolation of the urogastrones-inhibitors of gastric acid secretionfrom human urine. Hoppe-Seyler's Zeitschrift für Physiologische Chemie, 356, 1765-1774.

Grossman, M. I., Adelson, J. W., Rothman, S. S., Brown, J. C., Said, S. S., Lin, T. -M., Chance, R. E., Gerring, E. L.,
Gregory, H., Glass, G. B. J., Andersson, S., Nasset, E. S., Sasaki, H., Faloona, G. R., Unger, R. H., Creutzfeldt, W., Kokas, E., and Thompson, J. C. (1974). Candidate hormones of the gut. Gastroenterology, 67, 730-755.

Hollenberg, M. D., and Gregory, H. (1976). Human urogastrone and mouse epidermal growth factor share a common receptor site in cultured human fibroblasts. Life Sciences, 20, 267-274.

Pearse, A. G. E., and Polak, J. M. (1975). Bifunctional reagents as vapour- and liquid-phase fixatives for immunohistochemistry. Histochemical Journal, 7, 179-186.

Polak, J. M., Bussolati, G., and Pearse, A. G. E. (1971). Cytochemical, immunofluorescence and ultrastructural investigations on the antral $\mathrm{G}$ cells in hyperparathyroidism. Virchows Archiv Abt. B Zellpathologie, 9, 187-197.

Sandweiss, D. J., Saltzstein, N. C., and Farbman, A. (1938). The prevention of healing of experimental peptic ulcer in Mann-Williamson dogs with the anterior pituitary-like hormone (Antruitrin-S); a preliminary report. American Journal of Digestive Diseases and Nutrition, 5, 24-30.

Starkey, R. H., Cohen, S., and Orth, D. N. (1975). Epidermal growth factor: indentification of a new hormone in human urine. Science, 189, 800-802.

Sternberger, L. A. (1974). Immunocytochemistry. PrenticeHall: Englewood Cliffs, New Jersey.

Turkington, R. W., Males, J. L., and Cohen, S. (1971). Synthesis and storage of epithelial-epidermal growth factor in submaxillary gland. Cancer Research, 31, 252-256.

Uvnäs-Wallensten, K. (1978). Vagal release of antral hormones. Chapter 64. In Gut Hormones. Edited by S. R. Bloom; Churchill Livingstone: Edinburgh. (In press).

Van Noorden, S., Heitz, P., Kasper, M., and Pearse, A. G. E. (1977). Mouse epidermal growth factor: light and electron microscopical localisation by immunocytochemical staining Histochemistry, 52, 329-340. 